\title{
Subsequent Identification of a Connective Tissue Disease Amongst Patients with Idiopathic Pulmonary Fibrosis : A Long- term Observational Study in 527 Patients
}

Byeong-zu Ghang

Jeju National University College of Medicine and Graduate School of Medicine https://orcid.org/0000-0001-7284-4964

So Hye Nam

Asan Medical Center

Jungsun Lee

Asan Medical Center

Doo-Ho Lim

Ulsan University Hospital

Soo Min Ahn

Asan Medical Center

Ji Seon Oh

Asan Medical Center

Seokchan Hong

Asan Medical Center

Yong-Gil Kim

Asan Medical Center

Bin Yoo

Asan Medical Center

Jinseok Kim

Jeju National University College of Medicine and Graduate School of Medicine

Chang-Keun Lee ( $\nabla$ cklee@amc.seoul.kr)

Asan Medical Center

\section{Research article}

Keywords: Autoantibodies, Autoimmunity, Idiopathic Pulmonary Fibrosis, Connective Tissue Diseases

Posted Date: October 8th, 2020

DOI: https://doi.org/10.21203/rs.3.rs-67863/v1

License: 두 (i) This work is licensed under a Creative Commons Attribution 4.0 International License. Read Full License 


\section{Abstract}

Background: Connective tissue disease (CTD) might occur during the course of idiopathic pulmonary fibrosis (IPF). Clinical factors associated with CTD development in IPF patients have still not been identified. We investigated which antibodies have a significant association with the development of CTD during the clinical course of IPF.

Methods: We retrospectively reviewed the records of 527 patients with a first diagnosis of IPF between January 2007 and March 2014 and investigated the time to CTD development after IPF diagnosis in these patients.

Results: CTD developed in 15 patients at a median of 2.1 years (range 1.2-4.8) after IPF diagnosis. All patients had anti-neutrophil cytoplasmic antibodies (ANCA) or autoantibodies that met the serology criteria for interstitial pneumonitis with autoimmune features. Survival duration for IPF patients with progression to CTD was $5.3(3.8,6.7)$ years, which was significantly longer than for IPF patients without progression to CTD $[2.9(1.7,4.8), p=0.001]$. Independent risk factors for CTD development in IPF patients included female gender [adjusted hazard ratio (HR) 5.319, $p=0.0082$ ], titer of rheumatoid factor (RF; adjusted HR, 1.006; $p=0.022$ ), titer of anti-citrullinated protein antibody (ACPA; adjusted HR, 1.009; $\mathrm{p}=0.0011$ ), and titer of myeloperoxidase (MPO)-ANCA (adjusted HR, 1.02; $\mathrm{p}<0.0001)$.

Conclusions: Progression to CTD is uncommon in IPF patients. However, a significant number of IPF patients with high titers of RF, ACPA, or MPO-ANCA progressed to CTD. RF, ACPA, and MPO-ANCA might be significantly associated with CTD development in IPF patients.

\section{Background}

Idiopathic pulmonary fibrosis (IPF) is a chronic disease characterized by pulmonary fibrosis and parenchymal destruction. $(1,2)$ Usual interstitial pneumonia (UIP) is the typical radiological and histopathological pattern of IPF. $(2,3)$ IPF is, by definition, UIP of unknown cause, and UIP is also observed in patients with connective tissue disease (CTD). Generally, CTD/UIP is diagnosed following investigation of patients with suspected UIP.(1) However, we sometimes encounter patients who progress to CTD during the clinical course of IPF/UIP and whose diagnosis changes to CTD/UIP.(4-7) Because CTD/UIP differs from IPF/UIP in treatment and prognosis, (8-12) it is important to predict the development of CTD during the clinical course of IPF/UIP. However, the cumulative incidence and predictive factors associated with the development of CTD during the clinical course of IPF remain unclear. These factors might be valuable clues for determining the pathogenesis of pulmonary fibrosis in patients with CTD.

Previously, we identified that the autoantibody-positive IPF patients were associated with a good prognosis; moreover, the use of immunosuppressants was associated with a better prognosis in these patients as opposed to the autoantibody-negative patients.(13) At present, autoantibody-positive IPF cases have not been classified as interstitial pneumonitis with autoimmune features (IPAF), and thus, the use of immunosuppressants is not recommended.(14) The clinical characteristics of autoantibody-positive IPF are similar to those of CTD/UIP patients.

We hypothesize that some IPF patients have a clinically significant association with autoimmunity, and that autoantibodies are important biomarkers for identifying these patients. Based on this hypothesis, we investigated whether the serology criteria presented above were associated with the development of CTD during the clinical course of IPF in the patients from our previous study, with a particular focus on which autoantibodies have a significant association with the development of CTD.

\section{Methods}

We retrospectively reviewed the records of 527 patients diagnosed with IPF by a multidisciplinary team (pulmonologist, radiologist, rheumatologist, and pathologist) assessing the results of high-resolution computed tomography or lung biopsy in a tertiary hospital from January 2007 through March 2014. The patients were followed up until April 2016 (for 2.4 [IQR, 1.1; 4.2] years). Information regarding demographics, medication, laboratory tests, bronchoscopy, and pulmonary function tests (PFT) was retrospectively collected from the institutional electronic medical records and entered into a database for analysis.

CTD-related symptoms were defined by the IPAF clinical domain. (15) IPF patients with suspected CTD-related symptoms or autoantibodies were evaluated by experienced rheumatologists, and those with CTD-related symptoms confirmed by a rheumatologist at the first visit to the clinic for IPF diagnosis (baseline) were excluded from this study. No clinical or morphologic 
manifestation suitable for the IPAF, were identified in the patients included in our study. We investigated the length of time from baseline to CTD diagnosis by an expert rheumatologist in IPF patients. Diagnosis of the specific type of CTD was made in accordance with the criteria from their corresponding societies.(16-20) We defined the survival duration of patients with IPF from their first visit to the clinic for IPF diagnosis to death, and we defined the baseline as the date of the first visit to the clinic for IPF diagnosis. Death was defined as cessation of national health insurance cover. Glucocorticoid (not for management of acute exacerbation) and immunosuppressants for immunomodulation were administered on an individual basis. The present study protocol was approved by the Institutional Review Board of Asan Medical Center (IRB number: 2016 - 0222).

\section{Tests for serologic autoantibodies}

The following antibodies were tested; this consisted of tests for anti-citrullinated peptide antibody (ACPA), antinuclear antibody (ANA), rheumatoid factor (RF), anti-dsDNA antibody, anti-Sm antibody, anti-RNP antibody, anti-Ro (SSA) antibody, anti-La (SSB) antibody, anti-Jo-1 antibody, anti-Scl-70 antibody, myeloperoxidase (MPO) anti-neutrophil cytoplasmic antibody (ANCA), and proteinase-3 (PR3) ANCA. Anti-synthetase syndrome Ab (except Jo-1), anti PM-Scl, anti-MDA-5 in the IPAF serologic domain were not tested because that was incompatible with current practice in ASAN Medical Center. Each untested autoantibody was considered autoantibody negative. Autoantibody tests were performed at the time of initial IPF diagnosis in most patients. These autoantibodies were repeatedly tested, usually 1-2 years after the first test in some patients.

\section{Statistical analyses}

Continuous variables are reported as means \pm standard deviations or medians and interquartile ranges (IQR), and categorical variables are presented as percentages. Differences between groups were evaluated by the Student's t test or the Mann-Whitney $U$ test for continuous variables, and by the $\chi 2$ or Fisher's exact test for categorical variables. Multivariable Cox proportional-hazards models with backward elimination were used to investigate the risk factors for the development of CTD. The proportional-hazards assumptions were assessed based on Schoenfeld residuals and log-log plots. Statistical significance was set at $p<0.05$. Statistical analysis was performed with R software (R Foundation for Statistical Computing, Vienna, Austria).

\section{Results}

Of the 527 IPF patients in the study, 42\% $(n=221 / 527)$ had autoantibodies, and $29 \%(n=153 / 527)$ had ANCA or autoantibodies that met the IPAF serology criteria. (Fig. 1, Supplementary table 1). CTD developed in 15 (2.8\%) IPF patients, at a median of 2.1 [IQR, 1.24.8] years after the initial diagnosis of IPF [seven patients with rheumatoid arthritis (RA), one undifferentiated connective tissue disease, two Sjögren syndrome (SJS), one polyarteritis nodosa, and four microscopic polyangiitis (MPA), Tables 1 and 2]. All of these patients who progressed to CTD had either ANCA or any other tested autoantibodies that satisfied the IPAF serology criteria in the clinical course. Two IPF patients who progressed to RA had MPO-ANCA. A significant number of IPF patients with high titers of RF, ACPA, or MPO-ANCA tested at first visit to the clinic progressed to CTD (Fig. 2). Furthermore, four patients (RA case 1, 3, 6, and MPA case 12, Table 2), who initially had either a low titer or absence of RF, ACPA, or MPO-ANCA, were found to have high titers of these autoantibodies following progression to CTD. 
Table 1

Clinical features of patients who developed connective tissue disease during the course of idiopathic pulmonary fibrosis

\begin{tabular}{|c|c|c|c|c|c|c|c|c|c|c|c|c|c|c|c|}
\hline Case & 1 & 2 & 3 & 4 & 5 & 6 & 7 & 8 & 9 & 10 & 11 & 12 & 13 & 14 & 15 \\
\hline Age & 63 & 57 & 66 & 58 & 67 & 48 & 64 & 60 & 66 & 53 & 70 & 56 & 60 & 64 & 69 \\
\hline Gender & $\mathrm{F}$ & $M$ & $\mathrm{~F}$ & $M$ & $M$ & $\mathrm{~F}$ & $\mathrm{~F}$ & $\mathrm{M}$ & $\mathrm{F}$ & $\mathrm{F}$ & $M$ & $\mathrm{~F}$ & $\mathrm{M}$ & $\mathrm{F}$ & $\mathrm{M}$ \\
\hline $\begin{array}{l}\text { Diagnosis of } \\
\text { CTD }\end{array}$ & RA & $\mathrm{RA}$ & RA & $\mathrm{RA}$ & RA & RA & RA & UCTD & SJS & SJS & PAN & MPA & MPA & MPA & MPA \\
\hline $\begin{array}{l}\text { Time from } \\
\text { IPF } \\
\text { diagnosis to } \\
\text { CTD } \\
\text { development } \\
\text { (years) }\end{array}$ & 6.6 & 1.8 & 2.1 & 8.8 & 0.9 & 5.8 & 0.6 & 1.1 & 1.3 & 3.8 & 1.4 & 3.1 & 6.1 & 0.8 & 2.3 \\
\hline Death & $\mathrm{N}$ & $Y$ & $\mathrm{~N}$ & $\mathrm{~N}$ & $\mathrm{Y}$ & $\mathrm{N}$ & $\mathrm{Y}$ & $Y$ & $\mathrm{Y}$ & $\mathrm{N}$ & $\mathrm{Y}$ & $\mathrm{Y}$ & $Y$ & $\mathrm{~N}$ & $\mathrm{~N}$ \\
\hline $\begin{array}{l}\text { Survival } \\
\text { duration } \\
\text { (years) }\end{array}$ & 7.6 & 3.8 & 4.9 & 10.5 & 4.4 & 6.7 & 1.9 & 6.3 & 3.9 & 6.8 & 2.2 & 3.2 & 6.6 & 6.8 & 5.3 \\
\hline FVC\% & 79 & 69 & 80 & 84 & 74 & 80 & 68 & 85 & 83 & 83 & 82 & 102 & 71 & 83 & 53 \\
\hline DLCO $\%$ & 70 & 59 & 72 & 100 & 60 & 63 & 48 & 45 & 64 & 63 & 62 & 110 & 29 & 70 & 50 \\
\hline $\operatorname{ESR}(\mathrm{mm} / \mathrm{h})$ & 47 & 47 & 34 & 19 & 120 & 8 & 9 & 47 & 36 & 36 & 120 & 84 & 23 & 24 & 120 \\
\hline $\begin{array}{l}\text { CRP } \\
(\mathrm{mg} / \mathrm{dL})\end{array}$ & 0.1 & 0.26 & 0.1 & 0.07 & 0.24 & 0.1 & 0.19 & 8.19 & 0.22 & 0.22 & 1.79 & 0.1 & 0.91 & 0.1 & 15.57 \\
\hline $\begin{array}{l}\text { AZA (before } \\
\text { CTD } \\
\text { diagnosis) }\end{array}$ & $\mathrm{N}$ & $\mathrm{N}$ & $Y$ & $\mathrm{~N}$ & $Y$ & $\mathrm{~N}$ & $\mathrm{~N}$ & $\mathrm{~N}$ & $Y$ & $\mathrm{~N}$ & $\mathrm{~N}$ & $\mathrm{~N}$ & $\mathrm{~N}$ & $\mathrm{~N}$ & $\mathrm{~N}$ \\
\hline $\begin{array}{l}\text { CYC (before } \\
\text { CTD } \\
\text { diagnosis) }\end{array}$ & $N$ & $\mathrm{~N}$ & $\mathrm{~N}$ & $\mathrm{~N}$ & $N$ & $\mathrm{~N}$ & $\mathrm{~N}$ & $\mathrm{~N}$ & $\mathrm{~N}$ & $\mathrm{~N}$ & $Y$ & $\mathrm{~N}$ & $\mathrm{~N}$ & $\mathrm{~N}$ & $\mathrm{~N}$ \\
\hline $\begin{array}{l}\text { CSA (before } \\
\text { CTD } \\
\text { diagnosis) }\end{array}$ & $\mathrm{N}$ & $\mathrm{N}$ & $\mathrm{N}$ & $\mathrm{N}$ & $\mathrm{N}$ & $\mathrm{N}$ & $\mathrm{N}$ & $\mathrm{N}$ & $\mathrm{N}$ & $Y$ & $\mathrm{~N}$ & $\mathrm{~N}$ & $\mathrm{~N}$ & $\mathrm{~N}$ & $\mathrm{~N}$ \\
\hline $\begin{array}{l}\text { MMF (before } \\
\text { CTD } \\
\text { diagnosis) }\end{array}$ & $\mathrm{N}$ & $\mathrm{N}$ & $\mathrm{N}$ & $\mathrm{N}$ & $\mathrm{N}$ & $\mathrm{N}$ & $\mathrm{N}$ & $\mathrm{N}$ & $\mathrm{N}$ & $\mathrm{N}$ & $\mathrm{N}$ & $\mathrm{N}$ & $\mathrm{N}$ & $\mathrm{N}$ & $\mathrm{N}$ \\
\hline \multicolumn{16}{|c|}{$\begin{array}{l}\text { AZA = azathioprine; CTD = connective tissue disease; CYC = cyclophosphamide; CSA = cyclosporine; DLCO = diffusing capacity of } \\
\text { the lung for carbon monoxide; ESR = erythrocyte sedimentation rate; CRP = C-reactive protein; FVC = forced vital capacity; IPF = } \\
\text { idiopathic pulmonary fibrosis; MMF = mycophenolate mofetil; MPA = microscopic polyangiitis; PAN = polyarteritis nodosa; RA = } \\
\text { rheumatoid arthritis; UCTD = undifferentiated connective tissue disease; SJS = Sjögren's syndrome. }\end{array}$} \\
\hline
\end{tabular}


Table 2

Autoantibody profiles in patients who developed connective tissue disease during the course of idiopathic pulmonary fibrosis

\begin{tabular}{|c|c|c|c|c|c|c|c|c|c|c|c|c|c|c|c|}
\hline Case & 1 & 2 & 3 & 4 & 5 & 6 & 7 & 8 & 9 & 10 & 11 & 12 & 13 & 14 & 15 \\
\hline $\begin{array}{l}\text { Diagnosis } \\
\text { of CTD }\end{array}$ & $\mathrm{RA}$ & RA & $\mathrm{RA}$ & RA & $\mathrm{RA}$ & $\mathrm{RA}$ & $\mathrm{RA}$ & UCTD & SJS & SJS & PAN & MPA & MPA & MPA & MPA \\
\hline RF 1st & - & 336 & - & - & 28 & - & 548 & - & - & NA & 34 & - & - & - & 127 \\
\hline$R F$ on $f / u$ & - & 696 & 513 & 19 & 41 & 325 & 181 & NA & - & - & 130 & 29 & NA & 32 & 49 \\
\hline ACPA 1st & - & 73 & 20 & 200 & $\begin{array}{l}> \\
340\end{array}$ & - & 340 & - & - & NA & NA & - & - & - & - \\
\hline $\begin{array}{l}\text { ACPA on } \\
f / u\end{array}$ & 14 & 32 & $\begin{array}{l}> \\
340\end{array}$ & 200 & $\begin{array}{l}> \\
340\end{array}$ & 274 & 340 & NA & - & - & - & - & NA & - & - \\
\hline ANA 1st & $1: 40$ & - & - & - & - & - & - & $1: 640$ & $1: 640$ & $1: 40$ & - & $1: 40$ & $1: 40$ & - & $1: 40$ \\
\hline ANA on $f / u$ & $1: 80$ & $1: 40$ & $1: 40$ & - & - & - & & $1: 640$ & $1: 320$ & $1: 40$ & - & NA & $1: 40$ & - & - \\
\hline $\begin{array}{l}\text { Anti- } \\
\text { dsDNA } \\
\text { antibody } \\
1 \text { st }\end{array}$ & - & NA & - & - & - & - & - & - & - & - & NA & NA & - & - & - \\
\hline $\begin{array}{l}\text { Anti- } \\
\text { dsDNA } \\
\text { antibody } \\
\text { on } \mathrm{f} / \mathrm{u}\end{array}$ & NA & NA & NA & NA & - & NA & - & NA & - & - & NA & - & NA & NA & NA \\
\hline $\begin{array}{l}\text { Anti-RNP } \\
\text { antibody } \\
1 \text { st }\end{array}$ & - & - & NA & - & - & - & 14 & NA & - & - & - & - & - & - & - \\
\hline $\begin{array}{l}\text { Anti-RNP } \\
\text { antibody } \\
\text { on } \mathrm{f} / \mathrm{u}\end{array}$ & NA & NA & NA & NA & NA & - & NA & NA & - & NA & - & - & NA & NA & - \\
\hline $\begin{array}{l}\text { Anti-Sm } \\
\text { antibody } \\
1 \text { st }\end{array}$ & - & - & NA & - & - & - & - & - & - & - & - & - & - & - & - \\
\hline $\begin{array}{l}\text { Anti-Sm } \\
\text { antibody } \\
\text { on } f / u\end{array}$ & NA & NA & NA & NA & NA & - & NA & NA & - & NA & - & - & NA & NA & - \\
\hline $\begin{array}{l}\text { Anti-Ro } \\
\text { antibody } \\
1 \text { st }\end{array}$ & - & - & 32 & - & - & - & - & - & $>240$ & - & - & - & - & - & - \\
\hline $\begin{array}{l}\text { Anti-Ro } \\
\text { antibody } \\
\text { on } \mathrm{f} / \mathrm{u}\end{array}$ & NA & NA & NA & NA & - & - & NA & NA & $>240$ & NA & - & - & NA & NA & - \\
\hline $\begin{array}{l}\text { Anti-La } \\
\text { antibody } \\
1 \text { st }\end{array}$ & - & - & - & NA & - & - & - & - & 181 & - & - & - & - & - & - \\
\hline $\begin{array}{l}\text { Anti-La } \\
\text { antibody } \\
\text { on } \mathrm{f} / \mathrm{u}\end{array}$ & NA & NA & NA & NA & - & - & NA & NA & 144 & NA & - & - & NA & NA & - \\
\hline $\begin{array}{l}\text { Anti-Scl } \\
\text { antibody } \\
1 \text { st }\end{array}$ & - & - & - & - & - & - & - & - & - & - & - & - & - & - & - \\
\hline
\end{tabular}

ACPA = anti-citrullinated protein antibody; ANA = antinuclear antibody; $C T D=$ connective tissue disease; $M P A=$ microscopic polyangiitis; $\mathrm{NA}$ = not available; $\mathrm{PAN}$ = polyarteritis nodosa; RA = rheumatoid arthritis; $\mathrm{RF}=$ rheumatoid factor; UCTD = undifferentiated connective tissue disease; SJS = Sjögren's syndrome. 


\begin{tabular}{|c|c|c|c|c|c|c|c|c|c|c|c|c|c|c|c|}
\hline Case & 1 & 2 & 3 & 4 & 5 & 6 & 7 & 8 & 9 & 10 & 11 & 12 & 13 & 14 & 15 \\
\hline $\begin{array}{l}\text { Anti-Scl } \\
\text { antibody } \\
\text { on } f / u\end{array}$ & - & NA & NA & - & - & - & NA & NA & - & - & - & - & NA & NA & - \\
\hline $\begin{array}{l}\text { Anti-Jo-1 } \\
\text { antibody } \\
1 \text { st }\end{array}$ & - & - & - & - & - & - & - & - & - & - & - & - & - & - & - \\
\hline $\begin{array}{l}\text { Anti-Jo-1 } \\
\text { antibody } \\
\text { on } \mathrm{f} / \mathrm{u}\end{array}$ & - & NA & NA & - & - & - & NA & NA & - & - & NA & - & NA & NA & - \\
\hline $\begin{array}{l}\text { MPO- } \\
\text { ANCA 1st }\end{array}$ & - & - & - & - & - & 19 & - & - & - & - & - & - & $\overrightarrow{134}$ & 174 & 192 \\
\hline $\begin{array}{l}\text { MPO- } \\
\text { ANCA on } \\
\text { f/u }\end{array}$ & - & NA & NA & 38 & - & - & - & NA & - & - & NA & $>>$ & NA & 90 & $\overrightarrow{134}$ \\
\hline $\begin{array}{l}\text { PR3-ANCA } \\
1 \mathrm{st}\end{array}$ & - & - & - & - & - & - & - & - & - & - & - & - & - & - & - \\
\hline $\begin{array}{l}\text { PR3-ANCA } \\
\text { on } \mathrm{f} / \mathrm{u}\end{array}$ & - & NA & NA & - & - & - & - & NA & - & - & NA & - & NA & - & 20 \\
\hline $\begin{array}{l}\text { ACPA = ant } \\
\text { polyangiitis } \\
\text { undifferent }\end{array}$ & & $\mathrm{d} \mathrm{pr}$ & $\begin{array}{l}n \text { ar } \\
; P A\end{array}$ & & & & $\begin{array}{l}\text { an } \\
\text { A }\end{array}$ & $\begin{array}{l}\mathrm{y} ; \mathrm{C} \\
\mathrm{um}\end{array}$ & & $\begin{array}{l}\text { vet } \\
\mathrm{RF}\end{array}$ & Ie $\mathrm{d}$ & $\begin{array}{l}\text { se; } N \\
\text { d fac }\end{array}$ & $\mathrm{m}$ & copic & \\
\hline
\end{tabular}

IPF patients with progression to CTD were significantly younger than the IPF patients without progression to CTD, and had a significantly higher proportion of women, rheumatoid factor positivity, ACPA positivity, MPO-ANCA positivity, and presence of lymphocytes in bronchoalveolar lavage (BAL). The survival duration for the IPF patients with progression to CTD was 5.3 [3.8-6.7] years, which was significantly longer than the IPF patients without progression to CTD (2.9 [1.7-4.8] years, $p=0.001)$. The clinical demographic data, baseline results of the PFT, autoantibody profiles, medication, and outcomes for the overall patient group are summarized in Tables 3 and 4 . 
Table 3

Characteristics of patients who developed connective tissue disease during the course of idiopathic pulmonary fibrosis

\begin{tabular}{|c|c|c|c|}
\hline & $\begin{array}{l}\text { IPF without progression to CTD } \\
(\mathrm{N}=512)\end{array}$ & $\begin{array}{l}\text { IPF with progression to CTD } \\
(\mathrm{N}=15)\end{array}$ & $P$ value \\
\hline Age at baseline & $67.0[61.0-72.0]$ & $63.0[57.5-66.0]$ & 0.014 \\
\hline Gender, male & $412(80.5 \%)$ & $7(46.7 \%)$ & 0.004 \\
\hline Ever smoked & $358(71.6 \%)$ & $7(46.7 \%)$ & 0.071 \\
\hline IPAF serologic criteria or ANCA & & & $<0.001$ \\
\hline No autoantibody & $306(59.8 \%)$ & $0(0.0 \%)$ & \\
\hline Meets criteria & $138(27.0 \%)$ & $15100.0 \%)$ & \\
\hline Positive autoantibody but does not meet criteria & $68(13.3 \%)$ & $0(0.0 \%)$ & \\
\hline \multicolumn{4}{|l|}{ Autoantibody (tested number) } \\
\hline Rheumatoid factor $(n=520)$ & $56 / 505(11.1 \%)^{\star}$ & $9 / 15(60.0 \%)^{\star}$ & $<0.001$ \\
\hline ACPA $(n=468)$ & $16 / 453(3.5 \%)^{*}$ & $6 / 15(40.0 \%)^{*}$ & $<0.001$ \\
\hline Antinuclear antibody $(n=525)$ & $44 / 510(8.6 \%)^{\star}$ & $4 / 15(26.7 \%)^{\star}$ & 0.053 \\
\hline Anti-dsDNA antibody $(\mathrm{n}=302)$ & $19 / 289(6.6 \%)^{*}$ & $0 / 13(0.0 \%)^{*}$ & 0.711 \\
\hline Anti-RNP antibody $(n=446)$ & $1 / 432(0.2 \%)^{\star}$ & $0 / 14(0.0 \%)^{\star}$ & 1.000 \\
\hline Anti-Sm antibody $(n=446)$ & $2 / 432(0.5 \%)^{*}$ & $0 / 14(0.0 \%)^{*}$ & 1.000 \\
\hline Anti-Ro antibody $(n=523)$ & $18 / 508(3.5 \%)^{\star}$ & $2 / 15(13.3 \%)^{\star}$ & 0.206 \\
\hline Anti-La antibody $(n=523)$ & $1 / 508(0.2 \%)^{*}$ & $1 / 15(6.7 \%)^{\star}$ & 0.060 \\
\hline Anti-Scl antibody $(n=518)$ & $1 / 503(0.2 \%)^{\star}$ & $0 / 15(0.0 \%) *$ & 1.000 \\
\hline Anti-Jo antibody $(n=514)$ & $1 / 499(0.2 \%)^{*}$ & $0 / 15(0.0 \%)^{*}$ & 1.000 \\
\hline MPO-ANCA $(n=517)$ & $23 / 502(4.6 \%)$ & $6 / 15(40.0 \%)$ & $<0.001$ \\
\hline PR3-ANCA $(n=517)$ & $4 / 502(0.8 \%)$ & $0 / 15(0.0 \%)$ & 1.000 \\
\hline Baseline 6MWT pulse (heart rate /min) & $113.5 \pm 17.7$ & $112.3 \pm 13.3$ & 0.802 \\
\hline Baseline $6 \mathrm{MWT} \mathrm{SaO}_{2}(\%)$ & $92.0[87.0-95.0]$ & $94.0[89.0-96.0]$ & 0.160 \\
\hline Baseline 6MWT Distance (m) & $440.0[360.0-500.0]$ & $445.0[390.0-483.5]$ & 0.865 \\
\hline Baseline FVC predicted (\%) & $68.4 \pm 16.6$ & $77.1 \pm 11.4$ & 0.046 \\
\hline Baseline DLCO predicted (\%) & $54.1 \pm 17.3$ & $64.3 \pm 20.1$ & 0.026 \\
\hline Baseline C-reactive protein (mg/dL) & $0.3[0.1-0.9]$ & $0.2[0.1-1.1]$ & 0.503 \\
\hline Baseline white blood cell $\left(* 10^{3} / \mu \mathrm{L}\right)$ & $8.0[6.7-9.8]$ & $7.2[5.5-9.3]$ & 0.235 \\
\hline BAL fluid nucleated cell count & $250.0[110.0-420.0]$ & $200.0[100.0-330.0]$ & 0.534 \\
\hline BAL fluid neutrophils (\%) & $11.0[4.0-27.5]$ & $6.5[4.0-55.0]$ & 0.817 \\
\hline BAL fluid lymphocytes (\%) & $10.0[4.5-18.0]$ & $20.0[10.0-24.0]$ & 0.038 \\
\hline \multicolumn{4}{|c|}{$\begin{array}{l}6 \mathrm{MWT}=6 \text { minute walk test; } \mathrm{ANCA}=\text { anti-neutrophil cytoplasmic antibodies; } \mathrm{BAL}=\text { bronchoalveolar lavage; } \mathrm{CTD}=\text { connective } \\
\text { tissue disease; } \mathrm{DLCO}=\text { diffusing capacity of the lung for carbon monoxide; } \mathrm{FVC}=\text { forced vital capacity; IPAF = interstitial } \\
\text { pneumonitis with autoimmune features; IPF = idiopathic pulmonary fibrosis; } \mathrm{SaO}_{2}=0 \text { xygen saturation. }\end{array}$} \\
\hline \multicolumn{4}{|l|}{ *Meet IPAF serologic domain } \\
\hline
\end{tabular}


Table 4

Medications and outcomes of idiopathic pulmonary fibrosis patients who developed connective tissue disease during the course of idiopathic pulmonary fibrosis

\begin{tabular}{|c|c|c|c|}
\hline & $\begin{array}{l}\text { IPF without progression to } \\
\text { CTD } \\
(\mathrm{N}=512)\end{array}$ & $\begin{array}{l}\text { IPF with progression to } \\
\text { CTD } \\
(\mathrm{N}=15)\end{array}$ & $P$ value \\
\hline \multicolumn{4}{|l|}{$\begin{array}{l}\text { Diagnosis of CTD developed during IPF disease } \\
\text { course }\end{array}$} \\
\hline - Rheumatoid arthritis & & $7(46.7 \%)$ & \\
\hline - Undifferentiated connective tissue disease & & $1(6.7 \%)$ & \\
\hline - Sjögren's syndrome & & $2(13.3 \%)$ & \\
\hline - Polyarteritis nodosa & & $1(6.7 \%)$ & \\
\hline - Microscopic Polyangiitis & & $4(26.7 \%)$ & \\
\hline Time to CTD development after IPF diagnosis (years) & & $2.1[1.2-4.8]$ & \\
\hline Steroid for immunomodulation & $184(35.9 \%)$ & $13(86.7 \%)$ & $<0.001$ \\
\hline Immunomodulator & $130(25.4 \%)$ & $12(80.0 \%)$ & $<0.001$ \\
\hline - Azathioprine & $86(16.8 \%)$ & $4(26.7 \%)$ & 0.514 \\
\hline - Cyclophosphamide & $10(2.0 \%)$ & $4(26.7 \%)$ & $<0.001$ \\
\hline - Cyclosporin & $53(10.4 \%)$ & $3(20.0 \%)$ & 0.441 \\
\hline - Mycophenolate mofetil & $22(4.3 \%)$ & $2(13.3 \%)$ & 0.305 \\
\hline - Methotrexate & $0(0.0 \%)$ & $5(33.3 \%)$ & $<0.001$ \\
\hline - Sulfasalazine & $0(0.0 \%)$ & $2(13.3 \%)$ & $<0.001$ \\
\hline - Tacrolimus & $6(1.2 \%)$ & $0(0.0 \%)$ & 1.000 \\
\hline - Sirolimus & $1(0.2 \%)$ & $0(0.0 \%)$ & 1.000 \\
\hline Mortality in 5 years & $302(59.0 \%)$ & $6(40.0 \%)$ & 0.228 \\
\hline Survival duration (years) & $2.9[1.7-4.8]$ & $5.3[3.8-6.7]$ & 0.001 \\
\hline
\end{tabular}

Among the IPF patients, independent risk factors for development of CTD in IPF patients included female gender (adjusted hazard ratio (HR) 5.319, $p=0.0082$ ), baseline titer of RF; adjusted HR 1.006, $p=0.022$ ), baseline titer of ACPA; adjusted HR 1.009, $p=0.0011$ ), and baseline titer of MPO-ANCA (adjusted HR 1.02, $p<0.0001$ ).

\section{Discussion}

CTD developed in 15 IPF patients during the clinical course of IPF/UIP. All these patients had ANCA or autoantibodies that met the IPAF serology criteria during the clinical course. RF, ACPA, and MPO-ANCA were important risk factors for the development of CTD in IPF patients, but antinuclear antibody (ANA) was not a risk factor. Progression to CTD is uncommon in IPF patients, but a significant number of IPF patients with high titers of RF, ACPA or MPO-ANCA tested at baseline progressed to CTD. Furthermore, there were four patients who initially had low titer or no RF, ACPA, or MPO-ANCA, but had high titers of these autoantibodies when progressed to CTD. This suggests that RF, ACPA, and MPO-ANCA may be significantly associated with the development of CTD/UIP, and that IPF/UIP with high titers of RF, ACPA or MPO-ANCA might be the initial clinical manifestation of CTD.(2, 21-23) High titers of RF, ACPA, or MPOANCA might be an important factor in the subsequent identification of CTD among patients with IPF. 
Development of CTD during the clinical course of IPF has not been well understood. Among lung disease patients with a high titer of ACPA in a previous study $(n=33)$, three developed the articular manifestations of RA during a median follow-up of 449 days.(24) Prior studies of patients with MPO-ANCA positive IPF found that $16-33 \%$ of patients subsequently developed MPA.(4-7) Similarly, out of 29 IPF patients with MPO-ANCA-positive IPF in our study, 4 (14\%) subsequently developed clinical manifestations of MPA. In these previous studies and our study, no IPF patients developed eosinophilic granulomatosis with polyangiitis or granulomatosis with polyangiitis. In our study, 11 of 15 IPF patients with progression to CTD had either RA or MPA. ACPA, RF, and MPO-ANCA were independent risk factors for the development of CTD in IPF patients. Considering this, IPF patients with RF, ACPA, and anti-MPO antibody might be associated with autoimmunity. ACPA, RF, and MPO-ANCA might play an important role in the development of UIP in patients with CTD. Furthermore, there were four patients who initially had low titer or no RF, ACPA, or MPO-ANCA, but had high titers of these autoantibodies when progressed to CTD. Thus, it would be a good option to periodically test these antibodies in IPF patients.

There have been studies on the type of interstitial lung disease (ILD) associated with rheumatic diseases. It is well known that UIP is more frequently observed in RA and MPA, which are associated with RF, ACPA and MPO-ANCA, than in other CTD. $(25,26)$ In ANCAassociated vasculitis, diffuse alveolar hemorrhage and pulmonary fibrosis are common pulmonary manifestations of MPA, associated with MPO-ANCA, but solitary or multiple nodules are typical chest image findings in patients with eosinophilic granulomatosis with polyangiitis or granulomatosis with polyangiitis.(27-30) It is also known that ILD is more frequently observed in seropositive RA patients than in seronegative RA patients. $(31,32)$ In addition, UIP is observed at a relatively low frequency in systemic lupus erythematosus, idiopathic inflammatory myopathy, systemic sclerosis, and mixed CTD, all of which have a high frequency of ANA. $(26,33)$ Considering this, it is reasonable to assume that there is an important association between the specific autoantibody and the type of ILD in CTD. In our study, RF, ACPA, and MPO-ANCA autoantibodies were significant risk factors for development of CTD in IPF patients, but ANA and PR3-ANCA were not. In conclusion, RF, ACPA, and MPO-ANCA might be importantly associated with the development of UIP with CTD. Testing for ANCAs, specifically MPO, is not part of the current major society recommendations for serologic evaluation in patients with suspected IPF or IPAF. $(1,15,34)$ Our findings suggest that in addition to testing for ACPA, RF, and ANA, measurement of MPO-ANCA may be indicated in patients with suspected IPF or IPAF.

In a Japanese IPF cohort, CTD developed in $9 \%$ of the patients (10/111 patients - 4 RA, 4 MPA, 1 SSc, 1 SSc/SJS) following an initial IPF diagnosis.(35) As in the Japanese IPF cohort, our study showed progression to RA and MPA, rather than the other CTDs, to be more common, with CTD progression more greatly observed among the lower age patients and females. However, they did not find autoantibodies to be significant risk factors for the development of CTD as ACPA was not tested and autoantibodies, with the exception of RF, ANA, and anti-dsDNA antibodies, were tested in only approximately half of the Japanese IPF patients; hence, their study could have a greater number of patients with false negatives compared to our study. Additionally, the Japanese study found that lymphoid aggregates with germinal centers were significant risk factors for development of CTD, which were not collected in our study. Notably, we observed a significantly higher lymphocyte percentage in BAL in IPF patients with CTD progression than in those without progression to CTD. However, we did not include lymphocyte percentage in BAL, which was assessed in approximately half of the patients, in the multivariable analysis. Hence, the factors that may be associated with autoimmunity in the diagnosis of suspected IPF patients include, relatively young age, sex (female), presence of RF, ACPA, or MPO-ANCA, lymphocyte percentages in BAL, and lymphoid aggregates with germinal centers in lung biopsy.

This study has several limitations in addition to those associated with being retrospective. Some patients had not been continuously visiting the hospital before death, and as a result, we may not know about the development of CTD in some cases. Nevertheless, the mean ratio of individual clinic follow-up duration to survival duration was 0.84. The IPF patients with development of CTD had a longer survival, and some patients who had stopped visiting the hospital came back and were diagnosed with CTD. In considering this, it is likely that there were not many cases of unknown CTD.

\section{Conclusions}

Autoantibodies have been identified in many IPF patients in previous studies, and some of these patients have been thought to be closely associated with autoimmunity. We observed development of CTD in IPF patients with ANCA or autoantibodies that met the IPAF serology criteria. Among these autoantibodies, RF, ACPA, and MPO-ANCA were significantly associated with the development of CTD in IPF patients. Progression to CTD is uncommon in IPF patients, but a significant number of IPF patients with high titers of RF, ACPA or MPO-ANCA progressed to CTD. IPF/UIP with high titers of RF, ACPA or MPO-ANCA might be the initial clinical manifestation 
of CTD. High titers of RF, ACPA, or MPO-ANCA might be an important factor in the subsequent identification of CTD among patients with IPF. Further studies are needed to investigate the role of RF, ACPA, and MPO-ANCA in development of pulmonary fibrosis.

\section{Abbreviations}

ACPA: anti-citrullinated peptide antibody; ANA: antinuclear antibody; ANCA: anti-neutrophil cytoplasmic antibody; CTD: connective tissue disease; ILD: interstitial lung disease; IPAF: interstitial pneumonitis with autoimmune features; IPF: Idiopathic pulmonary fibrosis; MPA: microscopic polyangiitis; MPO: myeloperoxidase; RA: rheumatoid arthritis; PR3: proteinase-3; RF: rheumatoid factor; SJS: Sjögren syndrome; UIP: Usual interstitial pneumonia.

\section{Declarations}

\section{Acknowledgments}

We would like to thank Hyojung Choi from Department of Clinical Research Information at Asan Medical Center for their assistance and in preparing this manuscript.

\section{Authors' contributions}

Study conception and design. BG, BY, and CK

Acquisition of data. BG, SHN and JL

Analysis and interpretation of data. BG, JL, SHN, SHL, SMA, JSO, SH, YGK, JK, BY, and CKL.

All authors read, and the report was approved.

\section{Funding}

This work was supported by the research fund of Rheumatology Research Foundation (RRF-2018-04)

\section{Availability of data and materials}

The datasets used and/or analyzed during the current study are available from the corresponding author on reasonable request.

\section{Ethics approval and consent to participate}

We retrospectively reviewed the records of IPF patients. The study was approved by the Institutional Review Board of Asan Medical Center (IRB number: 2016-0222).

\section{Consent for publication}

Not applicable.

\section{Competing interests}

The authors declare that they have no competing interests.

\section{References}


1. Raghu G, Collard HR, Egan JJ, Martinez FJ, Behr J, Brown KK, et al. An official ATS/ERS/JRS/ALAT statement: idiopathic pulmonary fibrosis: evidence-based guidelines for diagnosis and management. Am J Respir Crit Care Med. 2011;183(6):788-824.

2. Raghu G, Remy-Jardin M, Myers JL, Richeldi L, Ryerson CJ, Lederer DJ, et al. Diagnosis of idiopathic pulmonary fibrosis. An official ATS/ERS/JRS/ALAT clinical practice guideline. Am J Respir Crit Care Med. 2018;198(5):e44-e68.

3. Song JW, Do KH, Kim MY, Jang SJ, Colby TV, Kim DS. Pathologic and radiologic differences between idiopathic and collagen vascular disease-related usual interstitial pneumonia. Chest. 2009;136(1):23-30.

4. Liu GY, Ventura IB, Achtar-Zadeh N, Elicker BM, Jones KD, Wolters PJ, et al. Prevalence and clinical significance of antineutrophil cytoplasmic antibodies in North American patients with idiopathic pulmonary fibrosis. Chest. 2019;156(4):715-23.

5. Ando M, Miyazaki E, Ishii T, Mukai Y, Yamasue M, Fujisaki H, et al. Incidence of myeloperoxidase anti-neutrophil cytoplasmic antibody positivity and microscopic polyangitis in the course of idiopathic pulmonary fibrosis. Respir Med. 2013;107(4):608-15.

6. Kagiyama N, Takayanagi N, Kanauchi T, Ishiguro T, Yanagisawa T, Sugita Y. Antineutrophil cytoplasmic antibody-positive conversion and microscopic polyangiitis development in patients with idiopathic pulmonary fibrosis. BMJ Open Respir Res. 2015;2(1):e000058.

7. Hosoda C, Baba T, Hagiwara E, Ito H, Matsuo N, Kitamura H, et al. Clinical features of usual interstitial pneumonia with antineutrophil cytoplasmic antibody in comparison with idiopathic pulmonary fibrosis. Respirology. 2016;21(5):920-6.

8. Moua T, Zamora Martinez AC, Baqir M, Vassallo R, Limper AH, Ryu JH. Predictors of diagnosis and survival in idiopathic pulmonary fibrosis and connective tissue disease-related usual interstitial pneumonia. Respir Res. 2014;15:154.

9. Park JH, Kim DS, Park IN, Jang SJ, Kitaichi M, Nicholson AG, et al. Prognosis of fibrotic interstitial pneumonia: idiopathic versus collagen vascular disease-related subtypes. Am J Respir Crit Care Med. 2007;175(7):705-11.

10. Tashkin DP, Elashoff R, Clements PJ, Goldin J, Roth MD, Furst DE, et al. Cyclophosphamide versus placebo in scleroderma lung disease. N Engl J Med. 2006;354(25):2655-66.

11. Tashkin DP, Roth MD, Clements PJ, Furst DE, Khanna D, Kleerup EC, et al. Mycophenolate mofetil versus oral cyclophosphamide in scleroderma-related interstitial lung disease (SLS II): a randomised controlled, double-blind, parallel group trial. Lancet Respir Med. 2016;4(9):708-19.

12. Izumi S, likura M, Hirano S. Prednisone, azathioprine, and N-acetylcysteine for pulmonary fibrosis. N Engl J Med. 2012;367(9):869-71.

13. Ghang B, Lee J, Chan Kwon O, Ahn SM, Oh JS, Hong S, et al. Clinical significance of autoantibody positivity in idiopathic pulmonary fibrosis. Respir Med. 2019;155:43-8.

14. Raghu G, Rochwerg B, Zhang Y, Garcia CA, Azuma A, Behr J, et al. An Official ATS/ERS/JRS/ALAT Clinical Practice Guideline: Treatment of Idiopathic Pulmonary Fibrosis. An Update of the 2011 Clinical Practice Guideline. Am J Respir Crit Care Med. 2015;192(2):e3-19.

15. Fischer A, Antoniou KM, Brown KK, Cadranel J, Corte TJ, du Bois RM, et al. An official European Respiratory Society/American Thoracic Society research statement: interstitial pneumonia with autoimmune features. Eur Respir J. 2015;46(4):976-87.

16. Lightfoot RW, Jr., Michel BA, Bloch DA, Hunder GG, Zvaifler NJ, McShane DJ, et al. The American College of Rheumatology 1990 criteria for the classification of polyarteritis nodosa. Arthritis Rheum. 1990;33(8):1088-93.

17. Aletaha D, Neogi T, Silman AJ, Funovits J, Felson DT, Bingham CO, 3rd, et al. 2010 Rheumatoid arthritis classification criteria: an American College of Rheumatology/European League Against Rheumatism collaborative initiative. Arthritis Rheum. 2010;62(9):2569-81.

18. Shiboski SC, Shiboski CH, Criswell L, Baer A, Challacombe S, Lanfranchi H, et al. American College of Rheumatology classification criteria for Sjogren's syndrome: a data-driven, expert consensus approach in the Sjogren's International Collaborative Clinical Alliance cohort. Arthritis Care Res (Hoboken). 2012;64(4):475-87.

19. Jennette JC, Falk RJ, Bacon PA, Basu N, Cid MC, Ferrario F, et al. 2012 revised International Chapel Hill Consensus Conference Nomenclature of Vasculitides. Arthritis Rheum. 2013;65(1):1-11.

20. Mosca M, Neri R, Bombardieri S. Undifferentiated connective tissue diseases (UCTD): a review of the literature and a proposal for preliminary classification criteria. Clin Exp Rheumatol. 1999;17(5):615-20.

21. Wilfong EM, Lentz RJ, Guttentag A, Tolle JJ, Johnson JE, Kropski JA, et al. Interstitial pneumonia with autoimmune features: an emerging challenge at the intersection of rheumatology and pulmonology. Arthritis Rheumatol. 2018;70(12):1901-13. 
22. Vij R, Strek ME. Diagnosis and treatment of connective tissue disease-associated interstitial lung disease. Chest. 2013;143(3):814-24.

23. Hu Y, Wang LS, Wei YR, Du SS, Du YK, He X, et al. Clinical characteristics of connective tissue disease-associated interstitial lung disease in 1,044 Chinese patients. Chest. 2016;149(1):201-8.

24. Fischer A, Solomon JJ, du Bois RM, Deane KD, Olson AL, Fernandez-Perez ER, et al. Lung disease with anti-CCP antibodies but not rheumatoid arthritis or connective tissue disease. Respir Med. 2012;106(7):1040-7.

25. Kim EJ, Collard HR, King TE, Jr. Rheumatoid arthritis-associated interstitial lung disease: the relevance of histopathologic and radiographic pattern. Chest. 2009;136(5):1397-405.

26. Doyle TJ, Dellaripa PF. Lung manifestations in the rheumatic diseases. Chest. 2017;152(6):1283-95.

27. Homma S, Suzuki A, Sato K. Pulmonary involvement in ANCA-associated vasculitis from the view of the pulmonologist. Clin Exp Nephrol. 2013;17(5):667-71.

28. Mohammad AJ, Mortensen KH, Babar J, Smith R, Jones RB, Nakagomi D, et al. Pulmonary Involvement in Antineutrophil Cytoplasmic Antibodies (ANCA)-associated vasculitis: the influence of ANCA subtype. J Rheumatol. 2017;44(10):1458-67.

29. Schirmer JH, Wright MN, Vonthein R, Herrmann K, Nolle B, Both M, et al. Clinical presentation and long-term outcome of 144 patients with microscopic polyangiitis in a monocentric German cohort. Rheumatology (Oxford). 2016;55(1):71-9.

30. Fernandez Casares M, Gonzalez A, Fielli M, Caputo F, Bottinelli Y, Zamboni M. Microscopic polyangiitis associated with pulmonary fibrosis. Clin Rheumatol. 2015;34(7):1273-7.

31. Sahatciu-Meka V, Rexhepi S, Manxhuka-Kerliu S, Rexhepi M. Extra-articular manifestations of seronegative and seropositive rheumatoid arthritis. Bosn J Basic Med Sci. 2010;10(1):26-31.

32. Correia CS, Briones MR, Guo R, Ostrowski RA. Elevated anti-cyclic citrullinated peptide antibody titer is associated with increased risk for interstitial lung disease. Clin Rheumatol. 2019;38(4):1201-6.

33. Wells AU, Denton CP. Interstitial lung disease in connective tissue disease--mechanisms and management. Nat Rev Rheumatol. 2014;10(12):728-39.

34. Raghu G, Rochwerg B, Zhang Y, Garcia CA, Azuma A, Behr J, et al. An official ATS/ERS/JRS/ALAT clinical practice guideline: treatment of idiopathic pulmonary fibrosis. an update of the 2011 clinical practice guideline. Am J Respir Crit Care Med. 2015;192(2):e3-19.

35. Kono M, Nakamura Y, Enomoto N, Hashimoto D, Fujisawa T, Inui N, et al. Usual interstitial pneumonia preceding collagen vascular disease: a retrospective case control study of patients initially diagnosed with idiopathic pulmonary fibrosis. PLoS One.

2014;9(4):e94775.

\section{Figures}




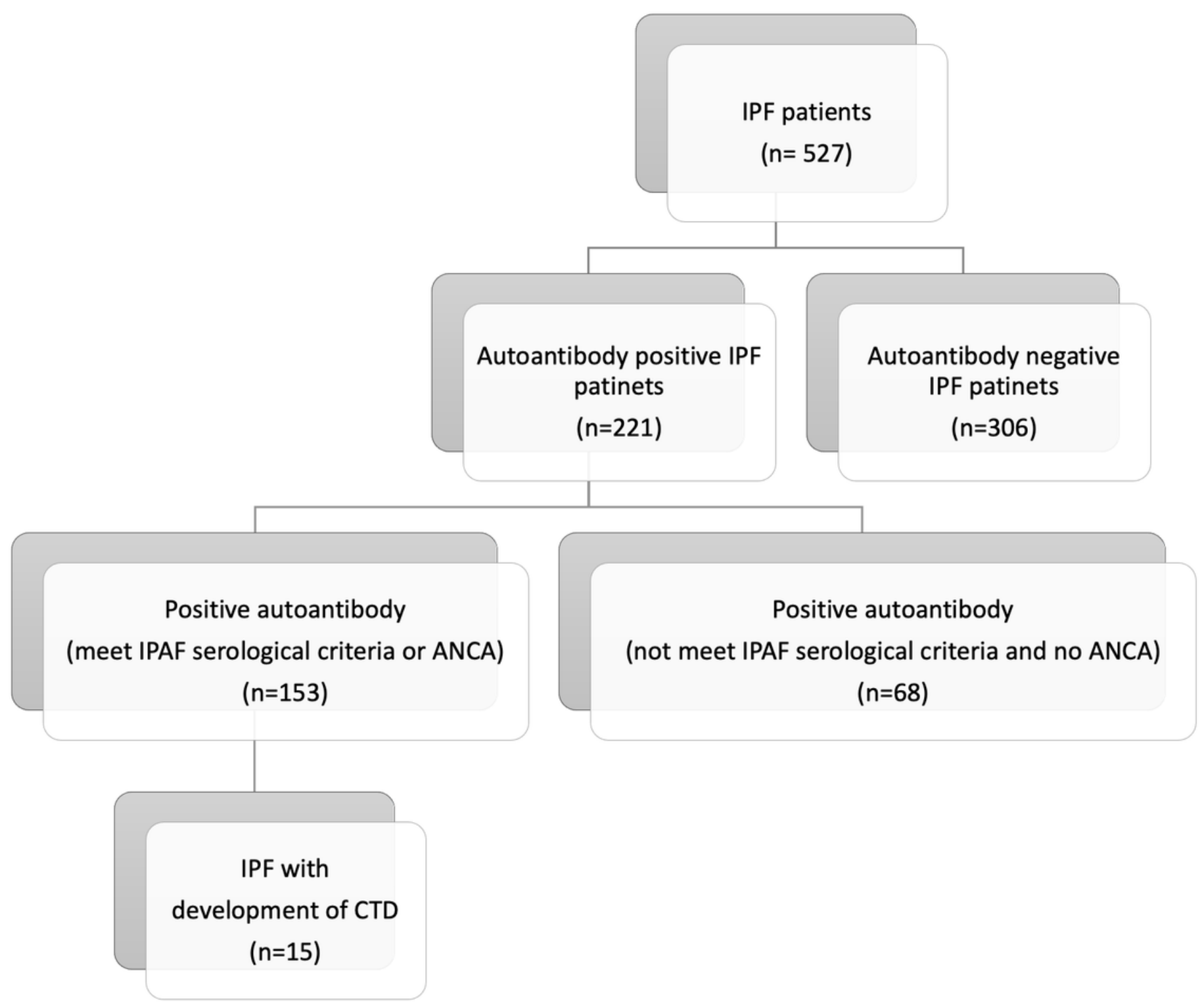

Figure 1

Flowchart representing the differentiation of IPF patients into distinct categories. ANCA = anti-neutrophil cytoplasmic antibodies; CTD = connective tissue disease; IPAF = interstitial pneumonitis with autoimmune features; IPF = idiopathic pulmonary fibrosis; 

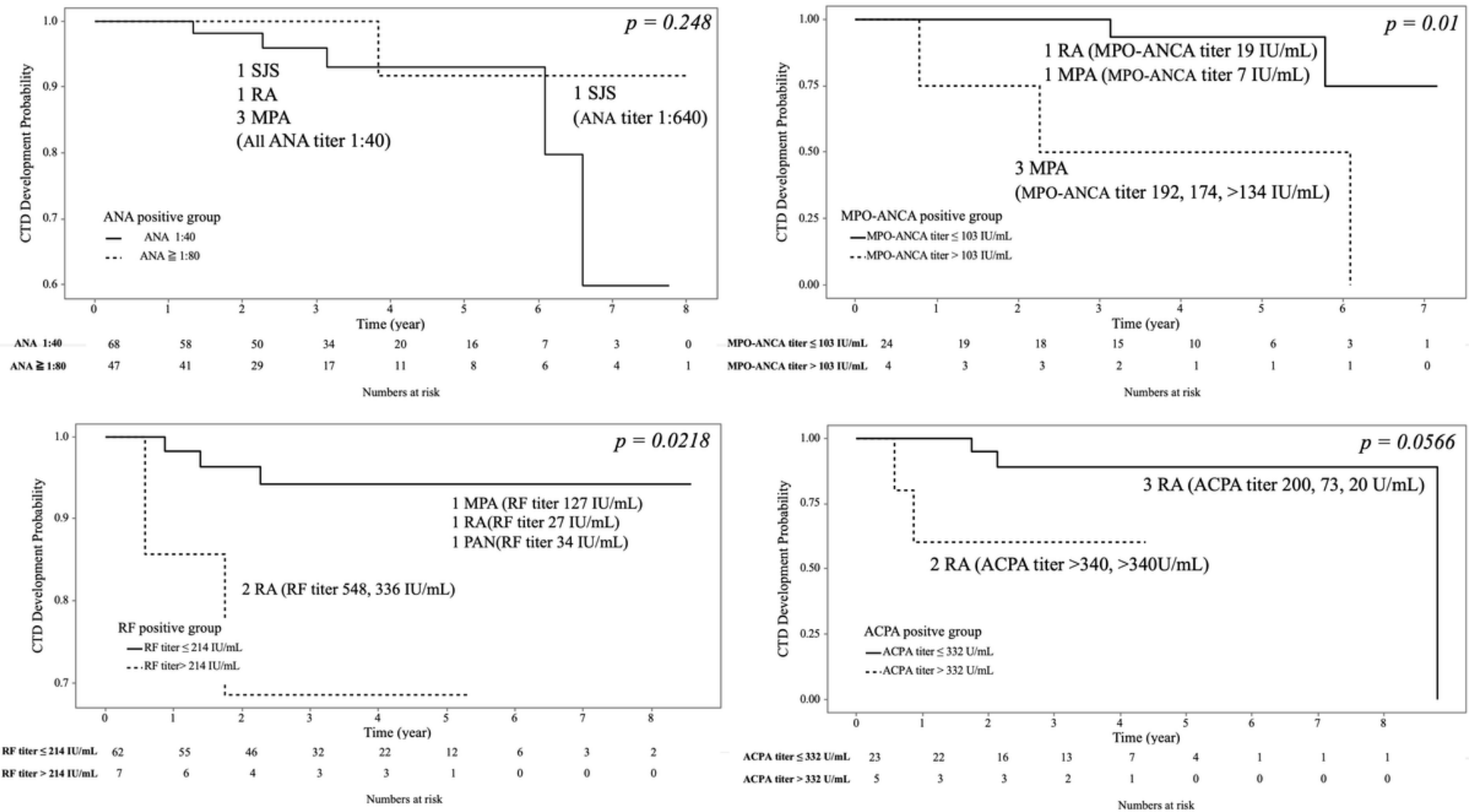

\section{Figure 2}

Development of connective tissue disease in each autoantibody-positive idiopathic pulmonary fibrosis patient. (autoantibody tested at baseline) $\mathrm{ACPA}=$ anti-citrullinated protein antibody; $\mathrm{ANA}=$ antinuclear antibody; $\mathrm{CTD}=$ connective tissue disease; $\mathrm{MPA}=$ microscopic polyangiitis; PAN = polyarteritis nodosa; RA = rheumatoid arthritis; RF = rheumatoid factor; UCTD = Undifferentiated connective tissue disease; SJS = Sjögren's syndrome.

\section{Supplementary Files}

This is a list of supplementary files associated with this preprint. Click to download.

- Supplementarytable1.docx 